УАК 316.354:174

ББК $60.55+87.754$

DOI 10.22394/1682-2358-2017-3-95-101

V.V. Nemolyaev, senior lecturer of the Tactics Department, Saratov Military Order of Zhukov Red Banner Institute of the National Guard of the Russian Federation

A.M. Pikbtelev, post-graduate student of the Humanities and Social Sciences Department, Saratov Military Order of Zhukov Red Banner Institute of the National Guard of the Russian Federation

\section{DESIGNING SOCIAL- PROFESSIONAL DEVELOPMENT OF THE RUSSIAN NATIONAL GUARD OFFICERS}

The essence of designing social development of the military organization of the Russian National Guard is revealed. The necessity of activating the processes of the social development project design for Russian National Guard officers is substantiated, and the role of social diagnostics in their implementation is specified. It is proved that designing the processes of social, economic, and professional perfection of officers under new conditions is manifested as the locomotive of the socio-economic development of the National Guard military organizations' human potential in general.

Key words and word-combinations: social construction, professional development, military organization.
В.В. Немоляев, старший преподаватель кафедри тактики Саратовского военного ордена Жукова Краснознаменного института войск наииональной гвардии Российской Федерачии (етаі): novochek2008@mail.ru)

A.M. Пихтелёв, адююнкм кафедри гуманитарньхх и социальньгх наук Саратовского Военного ордена Жукова Краснознаменного института войск национальной гвардии Российской Федерации (email: pikbtelev.a@bk.ru)

\section{КОНСТРУИРОВАНИЕ СОЦИААЬНО- ПРОФЕССИОНААЬНОГО РАЗВИТИЯ ОФИЦЕРОВ НАЦИОНААЬНОЙ ГВАРАИИ РОССИИ}

Аннотация. Раскрывается сущность конструирования социального развития военной организации национальной гвардии России. Обоснована необходимость активизации процессов проектного конструирования социального развития офицеров национальной гвардии России, уточнена роль социальной диагностики в их реализации. Доказано, что конструирование процессов социального, экономического, профессионального совершенствования офицеров проявляется как локомотив социальноэкономического развития человеческого потенциала военных организаций в целом.

Ключевые слова и словосочетания: социальное конструирование, профессиональное развитие, военная организация.

B условиях поиска выхода России из кризиса возникает необходимость целевого конструирования проџессов соџиального 
развития отдельных профессиональных групп наџиональной гвардии России: солдат, сержантов, прапорщиков, офиџеров. Важнейшим объектом данного конструирования явцяются офицеры. Соџиально-профессиональное развитие офиџеров - это, с одной стороны, показатель эффективности функционирования национальной гвардии России, с Аругой - результат целевого конструирования соџиального развития военной организации, формирование человеческого фактора ее социально-экономического самосовершенствования, обновления культуры служебно-трудовой деятельности военнослужащих в целом. Именно поэтому соџиальное конструирование сощиально-профессионального развития офицеров национальной гвардии России имеет как социальное, так и экономическое значение. Аанное конструирование нацелено на формирование нового качества профессионального капитала офицеров, а затем и их подчиненных, определяет организаџионный потенциал эффективного функционирования военной организации, рост результативности служебно-трудового взаимодействия военнослужащих, способствует росту сощиальной ответственности акторов национальной гвардии [1] .

Следовательно, в условиях перехода России к экономическому росту создаются финансовые условия осуществления проектного конструирования соџиального развития офиџеров наџиональной гвардии России. Служебнотрудовая эффективность в настоящее время определяется не только профессионализмом отдельных военнослужащих, но и уровнем профессиональной спиоченности, ответственностью офицеров, прапорщиков, сержантов, солдат. Основной объект Аанного соџиального конструирования - офиџер. Конструирование процессов профессионального совершенствования офиџеров в новых условиях проявцяется, как мокомотив соџиацьно-экономического развития чецовеческого потенциала военной организации национальной гвардии России в целом.

Рассмотрим подробнее теоретические и практические проблемы конструирования соџиально-профессионального развития офиџеров на примере военных организаций национальной гвардии России. Общие теоретические принџипы процесса соџиально-профессионального конструирования заложены в рамках конџепџии социального планирования. Соџиальное планирование традиционно рассматривается как механизм соџиацьно-профессионального конструирования соџиума, а также как фактор последующего преодоления социально-трудовых противоречий неопределенности функционирования организаџии размичного типа [2] .

Социальное конструирование Аолжно осуществцяться на основе анализа результатов соџиологической диагностики акторов военной организации. Его реализация связана с разработкой социальных проектов развития профессиональных групп организационного социума. Оно ориентировано на формирование оптимальных условий целевого развития профессионального потенциала тружеников [3]. Аанное конструирование определяет формирование системы социально ориентированных целевых проектов, определяющих развитие не только трудовой культуры, образовательных и здравоохранительных практик, но и профессионального потенциала работников, обеспечение их «потребностей в жилье, коммунальных услугах, коммуникациях [4]. В ре- 
зультате осуществления сощиального конструирования создаются условия разрешения трудовых противоречий в процессе адаптации трудовых субъектов к постоянно изменяющимся факторам внутренней, а также внешней среды военной организаџии [5]. При этом теоретики отмечают, что разработка и реализаџия проџесса соџиального конструирования может быть эффективна только в Авух случаях: 1) при создании соџиальной потребности (необхоАимости) в целевом достижении определенного типа соџиально-профессионального развития акторов; 2) при реализаџии проектов конструирования не только как приоритетной стратегии администраџии организаџии, но и как необходимости и добровольного выбора чиенов отдельных организаций.

По сути, соџиальное конструирование явмяется функџией соџиального внутриорганизационного регулирования, направценного на оптимизацию процессов соџиально-профессионального развития акторов. Социальное конструирование определяет целенаправленные трансформации, осуществляемые в рамках социально необходимых стратегий общества. На практике социальное конструирование представцяется как проџесс проектного формирования необходимых соџиальных изменений в качественных характеристиках работников организации. Соџиальное конструирование, с одной стороны, базируется на объективных предпосылках необходимости профессионального саморазвития работников, с Аругой - призвано обеспечить изменение качественных характеристик профессионального потенциала объекта конструирования.

Таким образом, процесс соџиального профессионального конструирования офиџеров военной организаџии связан с решением следующих задач: 1) оџенки проџесса профессионального развития офиџеров; 2) выявления проблем его осуществления; 3) уточнения механизмов проектного воздействия на офицеров как субъектов профессионального развития Аця обеспечения разрешения ранее обозначенных проблем [6]. В последующем могично выявить пути совершенствования профессионацьного развития офицеров в результате активизации механизмов социального конструирования, а также спрогнозировать вцияние Аанного совершенствования на эффективность труда офицеров. При этом всякое соџиацьное конструирование Аолжно основываться на результатах оџенки профессионацьного потенциала объекта проектирования.

Проанализируем некоторые результаты оценки профессионацьного потенциала офицеров; определим необходимость и возможность его Аальнейшего соџиального проектного конструирования; проведем вторичный анализ соџиомогического исследования «Профессиональное развитие офиџеров войск национальной гвардии России». Анкетный опрос был проведен в феврале - марте 2016 г., в войсковых частях Татарстана (Казань - 134 человек (33\%)), Нижегородской области (Богородск - 129 человека (31\%)), Саратовской области (Саратов - 149 человека (36\%)). В условиях полной определенности генеральной совокупности, наличия алфавитных списков исследуемого состава офиџеров применена случайная выборка: механический отбор каждого второго из общего алфавитного списка офицеров исследуемых войсковых частей $(n=412)$.

У офицеров возрастает в целом отношение к профессиональному потенциалу как жкизненно важной ценности, формируется мотив, опредемяющий необходимость его целевого развития. В ходе эмпирического исследования 
офиџерам было предложено ответить на вопрос: «Что в профессиональной деятельности офиџера Аля Вас является наиболее ценным?». Выясницось, что наиболее важной профессиональной ценностью офицеров по-прежннему является «перспектива получения материальной обеспеченности» (46\%). Второе место занимает ценность «интересной профессии» (39\%). Третье - «возможность испытать себя в сложных условиях» (38\%). Последующие ценности по значимости расположились следующим образом: «уважение со стороны окружающих» (38\%), «возможность получения жилья» (30\%), «возможность физического совершенствования» $(30 \%)$, «социальные мьготы и преимушества» $(29 \%)$, «возможность реализации патриотизма» (27\%). Несложно заметить, что потребность реализации патриотизма в процессе профессиональной деятемьности хотя и стала существенно значимой, но не занимает первоочередных позиций.

Таким образом, прослеживается тенденция, согласно которой по мере прохождения военной службы у офиџера возрастает значимость профессиональных ценностей. Аогичны изменения в системе ценности профессиональной деятельности, связанной с материальными предпочтениями офицеров. Проявмяется тенденщия роста значимости для военнослужащих интересной военной профессии, возможности испытать свои способности в проџессе реализаџии профессионального труда. «Интересная военная профессия» явмяется второй по значимости ценностью в профессиональной деятельности офицера. В системе профессиональной деятельности офиџера постепенно усиливается значимость профессионального потенциала, возможность проявить собственные симы в проџессе реализаџии интересной и общественно важной профессии.

Наблюдается повышение устойчивости военно-профессионального выбора офиџеров. Так, на вопрос: «Если бы у Вас была возможность снова выбирать профессию, то повторили бы Вы свой выбор?», - $65 \%$ респондентов ответими утвердительно. Только $17 \%$ Аали отрицательный ответ. При этом в процессе реализации военной службы 64\% офицеров изменили отношение к выбору профессии военнослужашего в Аучшую сторону. Изменили свое отношение к военно-профессиональному выбору в худшую сторону только $8 \%$ респондентов.

В целом офицеры удовлетворены выбором своей профессией, по мере реамизаџии проектов социальной реформы убежденность в правильности выбора только усиливается. Например, на время опроса у $59 \%$ офиџеров нет желания уволиться с военной службы, у $34 \%$ - иногАа возникало, но всегда проходило (в совокупности данный показатель составляет более 90\%). Подобная ситуация подтвержАает устойчивость желания осушествцять проектное развитие профессионального потенџиала офиџеров наџиональной гвардии.

Оказался предсказуем ответ на вопрос об удовлетворенности офиџеров служебно-трудовой деятельностью в военной организации. В настоящее время $79 \%$ офиџеров довольны своей профессиональной деятельностью, $15 \%$ - частично удовлетворены. Неудовлетворенными остаются только $6 \%$ опрошенных. Профессиональная удовлетворенность создает условия для успешности процесса последуюшего подписания контракта офиџерами. $69 \%$ опрошенных хотят продлить контракт после окончания его предыдущего срока.

В то же время офиџеры полагают, что в современных условиях проблема качественного выполнения офицерами своих профессиональных обязанностей 
явмяется актуальной (73\%). Подавляющее большинство опрошенных уверены в необходимости рассматривать и решать пробкему повышения качества выполнения офиџерами своей профессиональной деятельности. В џелом процесс профессиональной деятельности офиџера оџенивается положительно. $43 \%$ респондентов считают, что происходит постепенное, но уверенное повышение профессионализма офицерского состава. Выявлен высокий уровень самооценки собственного профессионального потенциала офиџеров. Так, на вопрос: «Считаете ми Вы свой уровень профессионального потенциала достаточным дмя эффективного выполнения служебно-трудовой деятельности?», - 19\% опрошенных отвечают положкительно, а $43 \%$ констатируют скорее «Аа», чем «нет». В совокупности показатель положительной оџенки составляет более $60 \%$.

Представленный показатель демонстрируется респондентами в контексте их завышенной самооџенки. Аанное предположение подтверждает и результаты анализа ответов на последующие вопросы анкеты. На вопрос: «Насколько часто возникают ситуации, когда Вы чувствуете недостаток профессиональной компетенции?», $33 \%$ офицеров отвечают - «часто». 59\% - «не часто», но имеют ситуации, когда чувствуют недостаток профессиональной компетенџии. Только у $8 \%$ офиџеров данные ситуаџии вообще не случаются (несомненно, это проявмение некоторой неискренности).

Таким образом, ответы на два представленных вопроса входят в некоторое противоречие Аруг с Аругом. С одной стороны, полученный результат позвомяет заключить, что респонденты склонны к завышенной самооџенке. Ведь уровень профессионализма офиџеров наџиональной гвардии явно нуждается в серьезной и существенной коррекции. Подавляющее большинство офиџеров понимает, что их уровень профессионализма недостаточен в контексте современных требований. С Аругой стороны, можно констатировать, что респонденты были несколько не искренними. Ведь в новых условиях недостаточность уровня профессиональной компетентности офицеров проявмяется по цемому перечню направлений. В современной системе наџиональной гвардии быстро меняется среда профессионального взаимодействия, идет постоянный прием новой техники, технических средств обработки и сбора информации. К тому же постоянно повышаются нормативы профессиональных компетенций, формируются новые цели и задачи профессиональной деятельности современного офиџера национальной гвардии России. С третьей стороны, проявляется дефиџит саморефлексионных практик офиџеров, а также частичная потеря офиџерским корпусом способности к соотношению требований и уровня их профессионального потенџиала. Офиџеры отказываются от критической объективной самоџјенки собственного профессионального потенџиала. Здесь проявмяется одна из серьезнейших проблем - недостаточность широты и динамичности системы военно-профессионального образовательного проектного развития офицеров. В данном контексте офицеры не всегда могут четко определить, какие характеристики профессионального потенџиала домжны быть им присущи в современных условиях, как они должны оптимизировать труАовую деятельность, организовывать процесс профессионального потребительного и џемевого конструирования процессов профессионального развития.

Не противоречат данным положениям и результаты анализа ответов рес- 
пондентов на вопрос: «Выполнение каких профессиональных функций преАставляет для Вас наибольшую сложность в современных условиях?». Аля 23\% респондентов сбор информации представляет серьезной проблемой; для $19 \%$ профессиональные пробцемы прежде всего связаны с анализом информаџии и уже на стадии типового планирования теряют остроту; только $6 \%$ опрошенных имеют профессиональные проблемы на стадии планирования служебнотрудовой деятельности.

Именно поиск, обработка, анализ и обобщение информаџионных потоков определяют основной бцок проблем профессиональной деятельности современного офиџера. Система профессионально-образовательной подготовки, видимо, не справляется с решением данной задачи, информационные программы профессиональной подготовки не явмяются достаточно адаптивными и эффективными в вопросах информаџионного обучения офиџеров. В рамках профессиональных практик поиска и обработки информации офицер в большинстве случаев вынужден опираться прежде всего на свои предылущие преАставления, здравый смысл, а порой просто на интуитивные представления. По-прежнему проявмяются факты решения возникающих служебно-трудовых противоречий офиџеров в рамках ранее имеющихся традиџионных практик. Решение поставленных профессиональных задач на практике осушествляется без применения информаџионно-технологических средств сбора, анализа и обработки информационных потоков. В данных условиях у офиџеров часто возникает завышенная самооценка собственного труда, имлюзия высокой эффективности собственной профессиональной деятельности. В современных условиях имеется множество проблем, связанных с неэффективностью работы офиџеров с информационными потоками, что, как правимо, приводит к снижению общей эффективности профессионального труда офиџеров.

Таким образом, в условиях формирования структур национальной гвардии России обновляется система конструирования профессионального развития офиџеров. В рамках военной организации осуществлен переход от упрощенного понимания профессионализма, рассматриваемого как комплекс формального профессионального образования офиџера (результат формального профессионально-образовательного усвоения ограниченного перечня военнопрофессиональных знаний, умений и навыков), к комплексной форме, ориентированной на комплексное соџиальное конструирование профессионального потенциала (результат комплексного образовательного и потребительного проектного развития общих и профессиональных знаний, умений, навыков, базовых профессиональных ценностей, норм, традищий).

Современный профессиональный потенџиал офиџера характеризуется преобладанием военно-профессиональных ценностей дисциплины, субординаџии, порядка, тотального контромя, послушания и всеобщего подчинения формальным, а также неформальным нормам, соџиально-административным ожиданиям вышестоящего руководства, жестким установлением индивидуальных ролей в организационной структуре полразделений. Профессиональный потенциал также характеризуется повышенной самооценкой офиџеров, низкой мотивацией офицеров к профессиональному саморазвитию, недостаточным уровнем развития навыков информационного сбора, анализа, обработки ин- 
формации, развития творческого инноваџионного потенциала офиџеров. В рамках деятельности современных офицеров только зарождаются практики командного творчества, рационализаторских действий в системе служебно-профессиональной деятельности трудовых групп. Пока не созданы благоприятные условия Аля цеелевого устойчивого конструирования научно-интелмектуального профессионального потенџиала офиџеров.

В новых условиях разрешение проблемных противоречий предусматривает необходимость цеменаправленного и планомерного обеспечения проџесса конструирования комплексного профессионального развития офиџеров: во-первых, через формирование многоуровневой системы стимулирования труда и профессионального развития (важно обеспечить не только постепенный рост материального Аовольствия офиџеров, но и внеАрить Авойственный механизм Аифференцированного материального стимулирования процесса непрерывного профессионального развития офиџеров); во-вторых, создание организаџионных условий Аля трудового творчества, реальных возможностей Аля новаторской деятельности офиџеров (формирование зон востребованности комплексных или частичных инновационных внеАрений, реализации факторов материального и нематериального стимулирования профессиональной иниџиативы и творчества); в-третьих, обновление системы оџенки профессионального развития и карьерного роста офицеров (интегральная оптимизация двух компонентов оџенки: узкой части профессионального потенщиала и широкой соџиокультурной части оџенки профессионализма в целом); в-четвертых, повышение эффективности системы профессиональной подготовки офиџерских каАров через модернизацию системы информационной подготовки, формирование рамок практической значимости процессов образовательного повышения квалификации, перспективного и стратегического карьерного роста офиџеров; в-пятых, внедрение программы соџиокультурного развития офиџеров посреАством проектной коррекџии и Аемократизации принщипов нестратегического управления научной, образовательной, научно-инновационной, бытовой деятельности офиџеров, формирование новых принципов в системе неформальных отношений офиџерского корпуса, достижение постепенного сближения формальных и неформальных социальных ценностей, норм, принщипов профессионального поведения офиџеров.

\section{Библиографический список}

1. Пихтелёв А.М. Социально-экономические концепции социального парнерства // Среднерусский вестник общественных наук. 2017. № 1 (12). С. 70-76.

2. Быченко Ю.Г. Развитие человеческого капитала в современном обществе // Вестник Саратовского государственного университета. 2013. № 3. С. 132-138.

3. Баландина T.M., Савенко А.А. Комплексная модель мотивационного принуждения трудоспособного населения к реализации трудовой деятельности // Вестник Саратовского государственного социально-экономического университета. 2015. № 4 (58). С. 94-97.

4. Райзберг Б.А., Лобко А.Г. Программно-целевое планирование и управление. М., 2002.

5. Кожевников B.B. Проблемы профессионализма сотрудников ОВД // Социологические исследования. 1999. № 9. С. 55-59.

6. Немоляев В.В. Многофакторная социологическая оценка профессиональной культуры // Вестник Поволжского института управления. 2016. № 2 (52). С. 86-93. 